\title{
The Tragic Hero of the Classical Period
}

\author{
Asuamah Adade-Yeboah ${ }^{1}$, Kwaku Ahenkora ${ }^{2} \&$ Adwoah S. Amankwah ${ }^{1}$ \\ ${ }^{1}$ Department of Communications, Christian Service University College, Kumasi, Ghana \\ ${ }^{2}$ Department of Business Studies, Christian Service University College, Kumasi, Ghana \\ Correspondence: Kwaku Ahenkora, Department of Business Studies, Christian Service University College, \\ Kumasi, Ghana. Tel: 233-54-556-9239. E-mail: k.ahenkora@yahoo.co.uk
}

Received: June 26, 2012

Accepted: July 19, $2012 \quad$ Online Published: August 20, 2012

doi:10.5539/ells.v2n3p10

URL: http://dx.doi.org/10.5539/ells.v2n3p10

\begin{abstract}
Just as tragic heroes and heroines have been identified with different eras and cultures, the classical ideal of the tragic hero will be incomplete if the concept of tragedy is not focalized. This paper, therefore, looks at how the classical period defined and delineated its tragic hero based on the action and the plot of the play. The paper provides extracts from Sophocles' King Oedipus as the main text and Euripides' Iphigenia in Tauris as a supporting text to present Oedipus as the tragic hero. Textual analysis shows that the delineation of the tragic hero lies in the source or context of the tragic situation. Sophocles and Euripides' views on the tragic hero are similar to Aristotle's concept of "hamartia" of the classical period.
\end{abstract}

Keywords: classical, Aristotle, harmatia, plot, action, Oedipus, tragedy, hero

\section{Introduction}

Tragedy as a thematic genre is best exhibited in drama because tragedy is of action and not character as Aristotle puts it. This proposition of Aristotle was followed to the hilt by the Greeks during their period of dramatic glory. The tragic drama of Aeschylus and his successors sprang from the ancient dithyramb; a choral song was chanted in honor of Dionysus. The 6th and 7th centuries BC saw some changes in this development. Individuals composed lines for celebrants. The choral leader was separated from the crowd, a development which led to the possibility of dramatic action. Sophocles and Euripides, prolific tragic dramatists, wrote at the time when old legends were looked at with skeptical eyes and the gods were no longer the awful forces to be afraid of. Aristophanes was one of the major dramatists of his times but he wrote comedies.

Among the classical dramatists, it is Sophocles who was much concerned with drama as an art form. His main preoccupation is that of art as verisimilitude. This is clearly demonstrated by his play, King Oedipus, one of a trilogy of Theban plays. In this play, one can find the best example of the Greek classical order. The ingenuity of the dramatist lay in his skill at arranging the plot to present the best tragic situation, based on the existing myths and legends. Sophocles however, took the fundamental Greek concept of law, crime and punishment into consideration. In a sense, the tragic drama in ancient Greece was an enactment of a ritual. Tragedy, unlike comedy, was not very popular outside Greece. Seneca's writings during this era cannot be forgotten. On his own, he adapted the known Greek tragedies. In his adaptations, he gave a new look to Greek tragedy by incorporating moral truths in his plays which were full of details, while his style of writing was unprecedented. Ancient tragedy is believed to have ended with Seneca.

Aristotle as an academic stands tall among all those who have considered tragedy as a literary form. In his book, The Poetics, (1963) he defines the elements which constitute the ideal tragic situation and how the ideal tragic hero should be portrayed. In chapter xiii, he states:

There remains then the man who occupies the mean between saintliness and depravity. He is not extra-ordinary in virtue and righteousness and yet does not fall into bad fortune because of evil and wickedness but because of some hamartia of a kind found in men of high reputation and good fortune such as Oedipus and Thyestes and famous men of similar families.

The most important word is hamartia, which means "a going wrong", which has a bearing on what the Greeks consider as the genuine tragic situation. It is an impetuous act which has no element of malice. Shakespeare uses as his source for creating the tragic situation. Unfortunately, the word "hamartia" has undergone misconceptions 
with regard to its proper translation from the Greek into English. Hamartia, in Greek tragedy is crucial in determining the source of the tragic situation. A critical analysis reveals that hamartia is of action and not of character. The meaning of hamartia in respect of the tragic hero underwent a drastic change during the Renaissance. The Renaissance critics were the first critics and commentators to have seen the original Greek text of The Poetics. They were the first to have translated the Greek hamartia in respect of the tragic hero to mean a "a weakness of character", instead of "a going wrong". They were the first to propound the moral doctrine, and insisted on the reading of the tragic hamartia as part of the character.

Aristotle demonstrated in The Poetics (1963) that Greek tragedy focuses on the action and the plot and not on character. Sackey (1992) has indicated the superiority of the Aristotleian plot in determining the tragic situation. This study, therefore, looks at how the classical period defined and delineated its tragic hero by providing extracts from relevant scenes of Sophocles' King Oedipus as the main text and Euripides' Iphigenia in Tauris as a supporting text to present Oedipus as the tragic hero.

\section{Method}

Of the various cultural productions of the Greeks, their tragedy offers the most convenient approach to their spiritual contribution because tragedy combines high art with profound thought. The reading of a Greek play is not exploring territory wholly uncharted. However, to judge ancient tragedy by gauges appropriate to the modern era can be misleading, for the premises and objectives of the Greek plays are different from those of the modern. Hamersley's (2008) views are crucial to readers of any work of art when he says, "the task is not just to produce a reading of a particular "text" but also to use this to illuminate general issues about human life." Textual analysis will be used for the purpose of an effective presentation of the classical tragic hero. The basis of this is to evoke the views of Aristotle (Termizi \& Ching, 2012):

The poet aims at the representation of life; necessarily, therefore, he must always represent things in one of three ways: either as they were or are, or as they said to be, or as they ought to be.

With such a close reading approach, the action and the plot of the text which are paramount to the concept of the classical tragic hero rather than character will be central to the analyses. This closeness and a systematic observation of the text as Brown (1990) observes will not restrict the free play of the inauguration or reductively limit the opportunities available for effective performance. Rather it will bring into more exciting relationship the most provocative features of a dramatic work.

\section{Results and Discussion}

\subsection{The Plot and the Imitation of Action}

Greek drama grew out of religious rituals and was presented as part of a religious cult. The religious association is indicated by the place and occasion of presentation, and it controls the structure of the plays and the mode of their presentations, the choice of subjects and themes, as well as the attitude of the playwrights and of their audience. The theatre of Dionysus at Athens, where the plays were presented, was part of the sacred precinct of that divinity. The plots of the tragedies were almost all drawn from the great body of traditional myth, which was esteemed almost as a species of scripture. In the source, only the bare bone of a story might be given, without the how or why or therefore. For example, a Clytemnestra murders an Agamemnon, who is then avenged by an Orestes. The dramatist proceeds to show the character and motivation of personages who could so behave and what their behavior can mean to the rest of us. All the principal personages must be of heroic stature; the fate of little men may be very sad, but cannot be tragic. Warrington (1965) cites Aristotle's hero, Oedipus, in King Oedipus as classic example of a tragic character and of a tragedy and from this perspective translates as follows:

The imitation of an action that is serious, has magnitude, and is complete in itself; in language with pleasurable accessories, each kind introduced separately in different parts of the work; in a dramatic as distinct from a narrative form, with incidents arousing pity and fear, whereby to provide an outlet for such emotions.

Tragedy, by implication, is an "action that is serious". The action is linked up with the plot because the plot is the imitation of the action. In other words, the plot is the synthesis of the individual acts. The word "serious" means that the action must surround a person of high class, an aristocrat. Again the action must call for attention. This must not be through narration but by dramatization. The above description of serious action can clearly be seen in King Oedipus in the sense that, Oedipus is of a noble birth. He is seen to be the one whose ignorance in committing incest and patricide is soon found out. The second element to look for is "the completeness of the action". This means that a complete action is that which has a beginning, middle and an end. A beginning is what does not, of necessity, come after something else but after which something else naturally happens. An end, on the contrary, is that which necessarily happens after something else, but which has nothing after it; and middle is 
that which has come after something and has something after it. Therefore from this explanation it is necessary that plots should neither begin where they neither chance to nor end-where they chance to, but to conform to the above. Oedipus' birth and growth in the home of Merope and Pelops and the killing of king Laius and the solution to the riddle of the monster are all outside the plot. Euripides' Iphigenia in Tauris has a similar plot. For example, Iphigenia's sacrifice of blood to Artemis of Aulis through Odysseus' craft is made abortive through Artemis who steals her and replaces her with a deer. This account is not put in the plot. The two accounts are things which happened in Greek mythology. Both Sophocles and Euripedes artistically weave these myths into the drama.

Sophocles, for example, makes the beginning of the play where Oedipus assumes his kingship on the Theban land, while Euripides begins the play at Taurianland where Iphigenia is taken to be a priestess. The middle of the action is where most of the actions are seen and where Oedipus, for example, becomes a king and marries his mother in ignorance. Iphigenia at this stage is also taken to Taurianland, for sacrifice to their gods. It is here that Orestes and his cousin Pylades are brought before Iphigenia who earlier on has expressed her vengeance on the Greeks:

... and my vengeance on the Greeks: therefore, whoever you may be that have come here, you shall find me cruel (Iphigenia in Tauris, p.69).

These illustrations constitute actions in the middle of the two plays. The putting together of the separate actions is very crucial. The beauty of the plot therefore lies in the arrangements which must have magnitude and not be a matter of chance. Indeed, the subtle manipulation of the plot which brings suspense also ends in the discovery. There is a mental torment of the hero to create and analyze situations so he can take a stand. The element of plausibility is important to the plot. Sophocles must therefore choose probable impossibility rather than incredible possibility. In other words, the plot should be made up of improbable parts. But if the unreasonable cannot be avoided it should be outside the plot. For example, Oedipus does not know how king Laius comes to his death. Again, Iphigenia does not know how she herself is brought to Taurianland.

The conclusion and the end are very crucial, after which nothing happens because the end of the play reveals whether the actions contain happiness or unhappiness. For example in King Oedipus, Oedipus, the tragic hero, is banished, his eyes taken out of their sockets. Simply, he is the culprit who has defiled the land and hence must suffer. The chorus aptly expresses sympathy at the end of the play: I weep for you and cry a dirge of lamentation. (King Oedipus, p. 68)

That obviously is a sad end and this unhappiness resides in the action imitated in the play. On the contrary, Euripides creates an end after the middle-packed actions. We see in the drama that Orestes who is to be sacrificed is saved due to the discovery. But for Orestes to be freed from the doom of the gods, the image of Artemis must be taken back to Greece including Iphigenia who must run away with her brother. This is done to end the play in happiness as expressed by the chorus again:

Go and go with you

Rich and Fortune's favour

Numbered with the living!

(Iphigenia in Tauris, p.86)

The happiness at the end once again resides in the action of the tragic heroine. Aristotle believes that the language must be sweet in tragedy. The level of language used by different characters should differ to depict the social stands of the characters. Horace calls this propriety in the use of language. For example, king Oedipus, who is temperamental, speaks to reveal his kingly utterance:

"Children, new blood of Cadmus' ancient line

What is the meaning of this supplication?"

(1, pp.1-2)

\subsection{The Tragic Hero and Fate}

The important thing for consideration is the tragic hero and the tragic situation. The proper tragic hero is defined by Aristotle as:

There remains then the man who occupies the mean between saintliness and depravity. He is not extraordinary in virtue and righteousness and yet does not fall into fortune because of evil and wickedness, but because of some hamartia of the kind found in men of high reputation and good fortune, such as Oedipus and Thyestes and 


\section{famous men of similar families.}

Sophocles' King Oedipus is not a drama of character where the tragic hero falls from grace to grass because of a tragic flaw, but a play of action in which the fall of the hero is occasioned by a final anagnorisis leading to a movement from ignorance to knowledge resulting in the hero's misfortune (Sackey, 1992). Oedipus is the royal birth-Son of king Laius. He is not pre-eminently virtuous and just but goes through ordeals in the play. King Oedipus is a play which can be described as a celebration of the divine force. The force is at its most rigid, unyielding and unpitying peak. This fact is revealed as the plot unfolds.

Prophecies in Greek tragedies are bound to be fulfilled in their true interpretation. Through prophecies man sees the power of the gods who only inform, leaving him in a wide scope of his thought and plans. In King Oedipus, we are made to see that man is not merely a passive sacrifice to his fate or destiny but that he actually takes an active part in it. But the gods arrange things in such a way that every step Oedipus takes in the hope of avoiding this fate only brings him nearer to it- an ironical situation but nevertheless, a means by which the power of the gods is exerted over man. The central theme of the play is divine credibility or the credibility of oracular pronouncements. The fact that the gods are infallible is made manifest and it is emphasized that if it were possible for the oracles to go wrong or to be untrue, human life would be meaningless. Thus there is a dichotomy between piety and reason. Piety is represented by the chorus who insist that the oracles cannot go wrong even if they appear to be so and reason is represented by Oedipus and Jocasta who maintains that the oracles are infallible because of the apparent facts. This implies doubting the infallibility of the gods and the elements of fate. The conflict at the heart of the play is between the ordained fate and the infallibility of the gods.

The major irony of the play pivots on Oedipus' relentless search for the murderer of king Lauis who is suspected by the gods to be residing in Thebes. Oedipus is ready to take offence or to impute blame when "raffled" by the approach of trouble; but he does not shirk in the performance of self appointed tasks unpleasant however; he is unflinching in the quest for the truth and at whatever cost. Oedipus is driven to the summit of passion through the agony of body and soul, and returns to humility and selfless resignation. He is a living portrait of a man, surrounded by a group of subsidiary portraits, who has no equal in Greek tragedy. The horror of the play is occasioned by the revelation that Oedipus kills king Laius, his father and marries Jocasta, his mother. This is followed by a reversal which proves to be a terrible exhibition of the unyielding course of fate. King Oedipus can be described as an analytic tragedy because the decisive events of the play, the patricide and the incest have already occurred before the play opens. Oedipus is already enmeshed in his fate as a result of his hamartia. Attempts at unraveling the mystery surrounding the problem of the plague only leads him deeper into the centre of the problem; which eventually leads to his destruction. The way in which the denouement and the reversal are achieved is remarkable. The two men, who in the past ensured that he lived, are the very harbingers of the news and the revelation. Therefore for harmony to be restored, the culprit must be punished appropriately to put right the harm done and to bring normalcy to the community. Thus it is very necessary for Oedipus, the tragic hero, to search for the murderer of Laius so that the person can bear his punishment and alleviates the suffering brought upon the Thebans. The single-mindedness with which Oedipus sets about the search leads him into the darkness and desolation. Sophocles is careful in the presentation of the hero. As a central protagonist, Oedipus appears in almost every scene and at various times, is juxtaposed with Teiresias, Creon and Jocasta to bring out the line of action Oedipus takes, the very ones which lead him to search so assiduously for the murderer of his predecessor. In fact the whole play is a supreme movement from ignorance to knowledge.

\subsection{Oedipus' Tragic Situation}

Oedipus is presented to us as a man of high integrity, resolute and unyielding in purpose but subject to the normal frailties of the human being. He is given to making rash decisions, sometimes, because of his zeal to do the right thing. However, the source of the tragic situation of Oedipus is not his temperamental disposition. The killing of his father can be the result of a combination of factors ignorance and temper - but the incest committed cannot be attributed to Oedipus' morality, a moral weakness. He is above all, a good king and an honest leader in whom his subjects have complete confidence. The faith the Thebans have in him springs from the fact that he is the stranger who came to Thebes to solve the problem of the Sphinx and to free their land from the plague. For his reward, he is given the Theban crown and their widowed queen who is offered to him in marriage. Oedipus is intellectually arrogant and demonstrates this in his actions, a fact which makes him hubristic. In remembering his feat with the sphinx, he feels intellectually equal to the present problem and rightly assumes the capability to solve it. This is echoed by the implicit faith the Thebans have in him and his abilities.

When the Thebans call on him to see what can be done about their problem, they find that in his diligence he has already sent Creon to the Delphic Oracle to ask what could be got from Apollo. The message Creon brings back 
is that the murderer of king Laius resides in their midst and that his presence has brought down the pestilence upon them. Thus Oedipus is ironically charged with the duty of finding the murderer and meting out the prescribed punishment. In this way, the impending doom is brought up even though it is not yet possible to discern where it is going to lead to, and the suspense which is one of the chief characteristics of the play is introduced. Quite typically, Oedipus pronounces what should be the sentence on the unfound culprit. Not only does he promise to leave no stone unturned to find the murderer, he also pronounces a curse of desolation and destruction on him:

I here pronounce my sentence upon his head: No matter who he

may be, he is forbidden shelter or intercourse with any man...

Expelled from every house, unclean, accursed

In accordance with the word of pythian oracle.

(1, pp.235-242)

His speech does not only show his earnestness and overzealous nature to get things done, but to get them done well. A job well done is a profound source of pride to him. Thus, he anticipates the end and assures his subjects of the return to normalcy, because the longstanding pollution must be expelled, and "not let it grow past remedy". To prove that he cares for his people and suffers more than any of them, Oedipus says:

"I grieve for you, my children. Believe me, I know all that

you desire of me, all that you suffer; and while you suffer,

none suffers more than $I$.

You have your several griefs each for Himself, but my

heart bears the weight for my own, and yours and all my

people's sorrows. I am not asleep.

(1, pp.93-98)

Thus, with steps which do not falter, Oedipus starts the journey which leads to his destruction, the journey into darkness and desolation. Tieresias aptly puts it thus:

"Then hear this: upon your head

Is the ban your lips have uttered...

You are the cursed polluter of this land.

(1, pp.382-384)

Teiresias' prophecy of condemnation is not taken seriously by anybody, especially, Oedipus. To Oedipus and everybody else this is quite an unexpected turn of event and a complete surprise as well as bewilderment even to the chorus who firmly believes and upholds the infallibility of the gods. This underscores the point that Oedipus has been haunted by his shadow since his youth. The gods set this trap for Oedipus and we cannot blame him for what he does.

The same plot structure informs Euripides' (1965) Hippolytus. In this drama, Theseus murders his son in ignorance of his son's true virtue. Clearly, we see Theseus' action as a hamartia and not a character trait. This much, Artemis confirms in her last speech where she exonerates Theseus: "His death was not yours, men may well commit hamartia when the gods so ordain."

Clearly, the goddess separates the doer from the deed and blames an external force rather than on depravity. It is in the same vein that we should view the character and action of Phaedra who perceives her attempt at incestuous relationship with her step son as an external madness rather than internal weakness of character. Much like Euripides, Aeschylus and Sophocles never intend their tragic heroes to fall into misfortune because of evil and wickedness caused by a defect in character. In other words, the Greek hamartia implies not what the character is but what the character does. In Greek tragedy therefore, character is not the essential element because it is not conceived that way. Aristotle considers four necessities of the tragic character which are good morals, appropriateness, true to life or true to the mythical prototype and consistency. A tragic flaw or a moral weakness of character has none of the above requirements nor does it have any implied meaning. Aristotle therefore rejects character as a necessity in tragedy. For this reason when there is a hint of human frailty of character because of its presence in the mythical origin, the flaw should be down played so as not to affect the goodness of the 
character".

Therefore, where Oedipus is heard saying, "my skill has brought me glory", he is not displaying arrogance as a character trait but showing his ability as a leader and a man of intellect. In the same way, Oedipus' lack of insight into Teiresias' speech: "And this success brought you ruin too".

A reply to Oedipus' earlier speech should not be taken to be pride and pomposity, but a clear indication of Oedipus' ignorance in his actions. Thus, Styan (1960) commented:

Truth can save or destroy, we continue; Oedipus will find insight when he

loses his sight, but his new knowledge will destroy, and in destroying him

may save him. In bearing his shame, he will live again with truth, and

both his destruction and salvation will depend upon his accepting his

shame and his penance of his sin. Oedipus will lose his life to find it.

The above extract is amply demonstrated in the life of the tragic hero because Oedipus gains insight in his sightlessness when the situation is reversed, after the revelation. Yet in all these we find in Oedipus the greatness of a man who is noble because of his readiness to accept and atone for his sins. A proper hero then, according to Aristotle, is not morally flawed. In moral terms Oedipus is placed in a definite context. That is, he must be good though not over virtuous or righteous and not a villain or a wicked man. Certain traits like cowardice should not be associated with a proper tragic hero like Oedipus. Hence when in King Oedipus the Theban shepherd is brought before Oedipus, the shepherd finds it difficult to disclose any information: "God help me but I am about to tell you dreadful tidings." (1, p.1124)

Oedipus, the proper hero who must not be a coward rather urges the shepherd to disclose the "dreadful tidings": "And I am about to hear them. But hear them I must". (1, p.1125)

Thus we see Oedipus' strong unflinching courage which does not falter despite his suspecting that he is the culprit he is seeking, even before the shepherd pronounces him to be the one. It takes a lot of courage, nobility shown by Oedipus to assist in his own demise.

\subsection{The Denouema}

The convergent threads of evidence meet in the final untying of the knot. The message Oedipus receives discloses that Polybus and Merope are not the parents of Oedipus. This made his belief concerning his parentage become to him a source of first anxiety and hope. This element of recognition is contrived in the best ways in both Sophocles' King Oedipus and Euripides' Iphigenia in Tauris. The reversals are particularly impressive because the Oedipus' Corinthian tidings are honourable, and Iphigena's tidings from both Orestes and Pylades are expected. The best recognition is the one arising from the events themselves in such a way that the shock of the discovery is produced according to probability, as in the two play mentioned above. For example, in Euripides' drama, recognition comes through a letter where Iphigenia recognizes her long lost brother. It is necessary for the dramatist as he composes tragedies to make a general scheme of his narrative, to fill in the episodes and give the work its full length. Aristotle cites Iphigenia in Tauris as the best Greek tragedy. Iphigenia who is about to be sacrificed to a god, is snatched away in a manner not clear to those sacrificing her. She is taken to another country (Taurisland) where the custom is to sacrifice strangers to the gods. At a later time, her brother happens to come to the temple (the fact that the god commanded him for some reason to go there is outside the plot). On his arrival, when Orestes is seized and is on the verge of being sacrificed, he recognizes his sister; then whether it is Euripides or Polydius who so arranges it, as probability requires, Orestes says it is necessary not merely for his sister but for himself to be sacrificed, and in that way, rescue comes. The deed of sacrificing Orestes is avoided because of sudden discovery. A tragic deed need not be committed for tragedy to be effected. In other words, a tragedy need not contain a hamartia and this drama is what Aristotle cites as the best tragedy without hamartia and also the most tragic.

Another best recognition is that which comes from syllogism. This is particularly true of King Oedipus. Oedipus recognises or rather discovers the truth of his parentage through a series of events, the discovery of which comes through a syllogism. But the deed is done in ignorance which is followed by full knowledge and understanding afterwards. This is what, once again, Aristotle sites as the best model of hamartia, because the tragic deed is done in the blindness of the moment and this occasion a momentary incapacity to understand and appreciate its meaning. The inevitable remorse which follows is therefore a clear movement to knowledge from an initial ignorance. This is Aristotle's best model of hamartia. Even though Aristotle judges Iphigenia in Tauris to be "the most tragic" in the work, the focus has been on King Oedipus which is the second best tragedy. This is because 
King Oedipus is the most pathetic in terms of suffering, that is, in terms of a reversal of fortune due in part to a hamartia, the chief Aristotelian criterion for "pathe". It is important however to juxtapose these two plays for the simple reason that even though Iphigenia in Tauris is the best tragedy, King Oedipus is the tragedy with hamartia and the best model of Aristotle's hamartia. In those two plays the tragic situations of Sophocles and Euripides are skillfully outlined in the plots in which the characters are placed. Aristotle says, it is possible for the deed not to be done at the last moment and this is what happens in Iphigenia in Tauris, where Iphigenia, a sister recognizes Orestes, a brother, and this forms the turning point in a play where hamartia is avoided. The avoidance of the harmatia in Iphigenia in Tauris allows the audience to achieve a catharsis. Pity and fear are no longer sustained because Orestes' murder is avoided and the audience's emotions are purged.

\subsection{The Tragic Harmatia}

The presentation of tragic hamartia where the tragic suffering is abundantly clear is best found in King Oedipus which has no equal in the Greek classical period. The wrong actions of Oedipus bring on certain blindness, which is not an inward blindness of disposition but a blindness of perception. Stated differently, the tragic suffering which occupies attention in most of this paper is not a result of moral blindness but emanates from an external incapacity due to ignorance. In the play, pity and fear are aroused through peripety and recognition. Aristotle states that tragedy must possess a good reversal and to achieve this there are two requirements. Firstly, tragedy must have a complex plot structure. Secondly, the incidence must arouse pity and fear. These fearful and pathetic happenings as we find in King Oedipus become the controlling concept to which all structural contributions are subordinated. These elements of pity and fear are the result of involuntary act of ignorance of a particular circumstance. Hence the chorus has this to say about Oedipus: "See him and see the breakers of misfortune swallow him".

Clearly, the fall of Oedipus is his hamartia. Sackey (1992) aptly states:

Aristotle's hamartia is simply a going wrong (not being wrong, for that will be an error of character which is (untragic) when the character is either ignorant of the particular wrong he is committing, (like Oedipus killing his father and marrying his mother in ignorance) or act in the heat of passion (like Orestes killing his mother to revenge his father's death). Under these circumstances Greek society prescribes appropriate sanctions against the culprit to right the wrong done. A tragic hero, by hamartia brings a dislocation of the natural order.

Oedipus' haunt lament after knowing the truth cannot be surpassed. His nobility is preeminently carried through and by accepting his fate and self-mutilation, asserts his heroic stature. In the closing scene of the drama, Sophocles evokes a touching feeling, where the anguish of Oedipus as regards the fate of his children (i.e. brothers and sisters) becomes so profound. He realizes the implication of the stigma they have to carry through life and he displays his fondness and loving care for their well being. He tells them he is sorry:

"For the unhappiness that must be yours:

And for the bitter life that you must lead."

$(1, p .432)$

With such sentiments he commits them into the care of their uncle Creon before he sets out for his life in desolation and want. The main cause of the fall of Oedipus therefore is his hamartia. There is no inordinate malice in him and he is basically a good man with a tragic fate. He is a typical Sophoclean hero. He is not extraordinary in virtue yet the misfortune which befalls him cannot be attributed to his evil deeds. It is simply because of a hamartia for, the hero is ignorant of the particular wrong he is committing and acts in the heat of passion.

Watling (1974) has this to say, about King Oedipus:

Its greatness lies in the combination of a faultlessly articulated plot with the profoundest insight into human motive and circumstances. Formally a story of the impact of quite fortuitous mischance upon a man of no exceptional fault of virtues, it lays bare with a ruthless sincerity worthy of its own protagonist, the pitfalls lying about the paths of man into which those very exceptional faults or virtues may at a touch over balance him, at the bidding of some incalculable chance, and out of which he must raise himself and be ennobled...

The extract above sums up the issues in the play. Watling (1974) also provides the perfect type of tragic composition as Aristotle does in the presentation of the proper tragic hero. This very extract tells us about Oedipus, the tragic hero, who is neither a saint nor a completely devilish person who tries to overcome, within his human limitations, the misfortunes that confront him and how he tries to solve them. If the gods deliberately plan Oedipus' fall they are to blame, and one wonders why a good man should be brought to the depths of ruin 
without letting him know why it all happens. Could it be just plain cruelty on their part? The intensity of the suffering of the hero, presented in this drama is extreme and unmitigated as seen at the end of the play. It is true that the suffering originates from the impetuosity of an unguarded moment but the punishment meted out is overwhelming. One cannot help but agree with Oedipus that it was indeed, Appolo who decreed he should suffer.

\section{Conclusion}

In an unusual way King Oedipus in its tragic clarity and purity enables us to experience tragic pleasure. From the time of the Greeks, the concept of tragedy has been exhaustively analyzed as a literary genre and satisfactorily justified as a philosophy. Sophocles, like any Greek writer and philosopher, has sought to relate the genre to actual life. His concept of tragedy explains and justifies the problems and woes of life Oedipus passes through. It must be observed that the delineation of the tragic hero lies in source of the tragic situation. It is expected that tragedy, being an artistic reflection of a collective religious experience imitate the culture to which it refers. Sophocles and Euripides' tragic heroes share similar views of Aristotle's concept of "hamartia" of the classical period.

\section{References}

Allan, H. Gilbert. (1962). Literary Criticism: Plato to Dryden. Detroit: Mayne State University Press.

Brown, J. R. (1990). Studying Shakespeare: A case Book. London: Macmillan Education Ltd.

Dorch, T. S. (1956). Classical Literary Criticism. London: Penguin.

Euripides. (1965). Iphigenia in Tauris. Harmondsworth: Penguin Book Ltd.

Hammersley, M. (2008). Questioning Qualitative Inquiry. London: Sage Publication Ltd.

Hegel. (1962). Hegel Tragedy. New York: Anchor Press. International Journal of Humanities and Social Science, 2(5), 246-254.

Sackey, A. A. (1992). "The Hamartia of Aristotle”, In The Dimensions of Comparative Literature. Accra: SMA.

Sophocles, E. A. (1974). King Oedipus. Harmondsworth, Penguin Book Ltd.

Styan, J. L. (1960). Elements of Drama. Cambridge: The University Press.

Termizi, A. A., \& Ching, T. A. (2012). Helicanus as 'A Figure of Truth, Faith and Loyalty' in Shakespeare's Pericles.

Warrington, J. (1965). The Poetics by Aristotle. London: J.M. Dent \& Sons Ltd.

Watling, E. F. (1974). The Thebian Plays by Sophocles. Harmondsworth: Penguin Books. 